\title{
Legislative Exclusion: Julian Bond and Adam Clayton Powell
}

\section{INTRODUCTION}

The initial refusal of the Georgia House of Representatives to seat Julian Bond and the successful challenge to Adam Clayton Powell in the United States House of Representatives have raised serious questions regarding the power of a legislative body to deny admission to a duly elected representative. In both cases, the legislative body questioned the fitness of a representative to serve even though he met the constitutionally stated qualifications of age, residence, and citizenship. ${ }^{1}$

Unlike the legislature's power to expel a member once seated, which, under the United States and most state constitutions, requires a twothirds majority, the power to exclude a member whom it finds unqualified for office can be exercised by a simple majority. Moreover, the United States Constitution, while granting Congress broad power to expel a member, ${ }^{2}$ apparently restricts Congressional power to judge qualification of members by enumerating certain requirements for office. $^{3}$ At least initially, Congressional practice conformed to this difference in the language of the Constitution by limiting its power of judging qualifications to an examination of the age, residence, and citizenship of members ${ }^{4}$ while relying upon the power to expel to purge itself of members who proved unfit for office. ${ }^{5}$

Although legislative exclusion has occurred throughout the nation's

1 Article I, section 2 of the United States Constitution declares: "No Person shall be a Representative who shall not have attained to the Age of twenty five Years, and been seven Years a Citizen of the United States, and who shall not, when elected, be an Inhabitant of that State in which he shall be chosen," while section 3 provides: "No Person shall be a Senator who shall not have attained to the Age of thirty Years, and been nine Years a Citizen of the United States, and who shall not, when elected, be an Inhabitant of that State for which he shall be chosen."

2 U.S. Const. art. I, \& 5. The Constitution provides: "Each House may . . punish its Members for disorderly Behavior, and, with the Concurrence of two thirds, expel a Member."

3 After enumerating the requirements for membership in article $I$, sections 2 and 3 , see note 1 supra, the Constitution declares: "Each House shall be the Judge of the Elections, Returns and Qualifications of its own Members. ..." U.S. Const. art. I, \& 5.

4 See, e.g., The Case of Albert Gallatin discussed in 1 A. Hinds, Precedents of THE HOUSE OF REPRESENTATIVES 413 (1907) [hereinafter cited as HiNDs].

5 See notes $37-42$ infra. 
history, ${ }^{6}$ the Supreme Court first considered the problem in the recent case of Bond $v$. Floyd. ${ }^{7}$ Bond, as Communications Director of the Student Non-Violent Coordinating Committee, had issued on behalf of the organization a statement criticizing the draft and the war in Vietnam in terms of the American Negro's struggle to achieve firstclass citizenship. ${ }^{8}$ In testifying before the committee appointed to investigate his qualifications, Bond expressed his admiration for the courage of those who burn their draft cards although he cautioned that he did not advocate such conduct and certainly would not engage in it himself. ${ }^{\ominus}$ Because of these statements, Bond was twice denied his seat in the Georgia House of Representatives. ${ }^{10}$ Speaking for a unanimous Court, Mr. Chief Justice Warren held that the Georgia Legislature had violated Bond's first amendment rights by excluding him from membership on the basis of his statements critical of the draft and the American involvement in Vietnam.11

With the exclusion of Adam Clayton Powell from the United States House of Representatives, the federal courts have once again been called upon to determine the constitutionality of legislative exclusion. ${ }^{12}$ Although Powell met the constitutional requirements of age, citizenship, and residence, the House concluded by a final vote of 307 to $116^{13}$ that he was not qualified for membership ${ }^{14}$ because he had failed

6 See notes 37-59 and accompanying text infra.

7385 U.S. 116 (1966).

8 For a full text of the statement, see 385 U.S. at 118-21.

9385 U.S. at 124.

10385 U.S. at $125,128$.

11385 U.S. at 137.

12 Powell v. McCormack, 266 F. Supp. 354 (D.D.C. 1967).

13 The vote was framed in terms of exclusion requiring only a majority vote. 113 Conc. Rec. H1942 (daily ed. March 1, 1967). The resolution did, however, pass by a twothirds majority on the final vote. Id. at H1957.

14 Upon presenting himself to the House, Powell's right to membership was challenged, and the House, adopting a resolution advanced by the minority leader, Representative Ford of Michigan, voted to refuse to administer the oath of office to Powell and to appoint a select committee headed by Representative Emanuel Celler of New York to inquire into his right to be seated. 113 Cong. Rec. H14-16 (daily ed. Jan. 10, 1967). The Celler committee, affirming the findings of the Hays subcommittee, proposed that Powell be allowed to take his seat but be punished with unprecedented severity by paying to the House $\$ 40,000$. Id. at H1919 (daily ed. March 1, 1967). The majority, demanding even harsher action, rejected the committee resolution by a vote of 222 to 202, with 8 not voting. Id. at H1941. A resolution was then introduced by Representative Curtis calling for the exclusion of Powell and was adopted by a vote of 248 to 176 . Id. at H1955. Only on the final vote, adopting the resolution as amended, was more than a two-thirds vote obtained. Id. at H1956. Because of the closeness of this vote and the temptation to vote with the winning side once the outcome was clear, it was probably decisive that the resolution was originally framed in terms of exclusion and not expulsion. 
to comply with orders of the New York courts ${ }^{15}$ and had been guilty of misusing public funds. ${ }^{16}$ Powell quickly appealed to the courts, alleging that the House had acted unconstitutionally in imposing additional qualifications for membership. In an opinion which emphasized the differences between the Powell and Bond cases, Judge Hart of the District Court of the District of Columbia dismissed Powell's complaint because it presented a nonjusticiable political question. ${ }^{17}$

Although in Bond the Court made it clear that a state legislature could not deny a federally protected right in exercising its power to judge the qualifications of members, the implications of the decision for the practice of the United States Congress in a case such as Powell's are far from clear. The doctrine of political questions-a hurdle not faced in reviewing state exclusions after Baker $v$. Carr ${ }^{18}$-continues to present an ostensible barrier to judicial review of the actions of a coordinate branch of the federal government. The possible confrontation between Congress and the judiciary over the right of a member to be seated has been vividly pointed out by the Powell case and could provide a new test of the doctrine of judicial supremacy. In addition, questions presented when a representative who meets the stated quali-

15 The shift in public and Congressional opinion that led to the exclusion of Powell resulted at least partially from his defiance of the authority of the New York courts. 113 Cong. Rec. H1918 (daily ed. March I, 1967). Powell's conflict with the judiciary began in October 1960, when Mrs. Esther James, whom he had branded "a bag woman for the New York City Police Department," commenced a libel suit against him. H.R. Rep. No. 27, 90th Cong., 1st Sess. 8 (1967). By January 1967, his failure to appear before the New York courts in actions which Mrs. James had brought for libel and fraudulent transfer of property had resulted in three judgments of civil contempt and one of criminal contempt. Indeed, at the time his right to membership in the House was first challenged, four orders for his arrest on charges of contempt were outstanding. Id. at 9-10.

16113 Cong. Rec. H1918 (daily ed. March 1, 1967). To the House this was perhaps the worst of Powell's offenses. Id. at H1933-36. In September 1966, in response to charges that Powell had misused airline credit cards issued to the Committee on Education and Labor, the chairman of the Committee on House Administration cancelled the credit cards issued to Powell's committee and launched an investigation under the chairmanship of Representative Hays of Ohio. H.R. RE. No. 27, 90th Cong., Ist Sess. I (1967). The Hays subcommittee held hearings in December 1966 to inquire into Powell's travel expenses and payments to his wife, Y. Marjorie Flores, whom he had employed as his clerk. The subcommittee concluded that Powell had indeed been guilty of wrongfully appropriating over $\$ 40,000$ of public funds by using his committee air travel card for private purposes and by allowing a salary to be paid to his wife who performed no official duties. H.R. REP. No. 2349, 89th Cong., 2d Sess. 6-7 (1966). Quickly following the report of the Hays subcommittee the Democratic members-elect of the 90th Congress voted to strip Powell of his office as chairman of the House Committee on Education and Labor. H.R. REP. No. 27, 90th Cong., lst Sess. 2 (1967).

17 Powell v. McCormack, 266 F. Supp. 354, 360 (D.D.C. 1967).

18369 U.S. 186, 210 (1962). In Baker the Court concluded that the political question doctrine was the product of the division of powers between coordinate branches of government and consequently did not bar federal review of state actions. 
fications for office is excluded for a reason other than statements protected by the first amendment remain unanswered by the decision in Bond.

\section{The Power of the Legislature}

\section{A. The Original Understanding}

In the Constitutional Convention most delegates, disagreeing with those who contended that the power to judge qualifications conferred upon Congress an unlimited power to examine the fitness of members, believed that a legislator could be excluded from Congress only if he failed to meet the qualifications for office stated in the Constitution itself. $^{19}$ The exclusion of the notorious John Wilkes from the British Parliament for a seditious libel of King George III was well known to the delegates. ${ }^{20}$ In that case, Parliament, dominated by the Crown, ${ }^{21}$ had succeeded in disqualifying Wilkes from membership for a period of eleven years even though he consistently received overwhelming majorities in elections held to fill his vacant seat. ${ }^{22}$ Madison expressed the views of many delegates when he cautioned that the abuse which

19 See C. WARren, The MARING of the Constrtution 420-22, 424 (1928). Dickenson, who argued against any recital of qualifications in the Constitution, was typical. He believed that the best defense lay in the freeholders who were to elect the legislature, not in the imposition of requirements for eligibility. "Whilst this Source remains pure the public interest would be safe. If it ever should be corrupt, no little expedients would repel the danger." 2 M. Farrand, The Record of the Federal Convention 123 (1937) [hereinafter cited as FarRand]. Such an argument was later made by Joseph Story in his commentaries on the Constitution. $1 \mathrm{~J}$. Story, Commentaries on the Constitution of the UnIted STATES 607 (5th ed. 1891).

20 Z. Chafge, free Speech in the United States 242 (1948). See J. Bect, Max It Please THE Court 292-95 (1930), for an account of Beck's defense against the expulsion of Senator Smith on charges of excess campaign expenditures before the Senate Committee on Privileges and Elections.

21 For a full account of the triumph of the Crown over the electorate see E. BurkE, Thoughts on the Causes of the Present Discontents, in 1 Works of EDaund BuRke 433-537 (1889).

22 The classic account of the struggle is contained in the standard biography of Wilkes: H. BLeAckiey, LIFE OF John WILKES (1917). See G. RUDE, WILKES AND LABERTY (1962), and W. TrezoAz, WILKES AND THE CITY (1917), for a fuller development of the political and social context of the sometimes violent efforts of the Middlesex electors to seat Wilkes. In the interesting parliamentary debates which accompanied his ejection, Wilkes' former enemy, Grenville, denied the power of Parliament to exclude a candidate merely because it thought him unfit for office and objected to the cumulative nature of the charges against Wilkes. He declared: "Is it not evident that, by this unworthy artifice, Mr. Wilkes may be expelled, although three parts in four of those who expell him should have declared against his expulsion upon every one of the articles contained in this charge." Grenville, Speech on the Motion for Expelling Mr. Wilkes, in 3 A Coluection or SCARCE AND INTERESTING TRACTS 13 (1787). Such a criticism of legislative judging has been forcefully restated in Z. Chafee, FreE SpEEch IN THE UNITEd STATEs 247-69 (1948). 
Parliament had made of its power to judge the qualifications of members in the Wilkes controversy "was a lesson worthy of our attention."23

During the debate over qualification two factions emerged. Those opposing a broad legislative power to exclude were led by Madison, who, like most members of the Convention, believed that "the qualifications of electors and elected ought to be fixed by the Constitution."24 If Congress could modify those of either, he felt it could subvert the Constitution and eliminate the power of the people to select their representatives. On the other hand, Gouverneur Morris and several other delegates ${ }^{25}$ argued that the legislature should be given complete freedom to establish qualifications. ${ }^{26}$ Unlike Madison, who considered the power of the legislature to expel a member too important to be exercised by a majority vote, ${ }^{27}$ Morris believed that a more stringent requirement would produce abuses by the minority. ${ }^{28}$ The Convention ultimately sided with Madison, and by a vote of seven states to three, ${ }^{29}$ defeated a proposal to give Congress the power to establish qualifications, and voted almost unanimously to require a two-thirds majority to expel a member. ${ }^{30}$

Writing in The Federalist, Hamilton gave strong support to Madison's position. Like many contemporaries, ${ }^{31}$ he concluded: "The qualifications of the persons who may choose or be chosen . . . are defined and fixed in the Constitution; and are unalterable by the legislature." 32

232 FARRAND 250.

24 Id. at 249-50.

25 See C. Warren, The Making of the Constrtution 420-21 (1928).

262 Farrand 250. This led Williamson of North Carolina to reply: "This could surely never be admitted. Should a majority of the Legislature be composed of any particular description of men, of lawyers for example, which is no improbable supposition, the future elections might be secured to their own body." Id.

27 Madison cautioned that: "[T] he right of expulsion was too important to be exercised by a bare majority of a quorum: and in emergencies of faction might be dangerously abused." 2 FARRAND 254.

$28 \mathrm{Id}$.

29 Id. at 251. See C. Warren, The Making of the ConstTtution 421 (1928), for a fuller discussion of the voting on qualifications.

302 FARRAND 254 . The proposal to require a two-thirds majority was approved by ten states with one state divided.

31 C. WARREN, THE MAKING OF the CONSTITUTION 424 (1928).

32 The Federalist No. 60, at 409 (Cooke ed. 1961) (Hamilton). At least one antifederalist writer took a contrary view. "Comelius," writing in the Hampshire Gazette, argued: "By this Federal Constitution, each House is to be the judge not only of elections and returns, but also of the qualifications of its members, and that, without any other rule than such as they themselves may prescribe. This power in Congress, I take to be equal to that of a negative on elections in general." (Emphasis in original.) Hampshire Gazette, Dec. 18, 1787, reprinted in C. WARREN, The MAKING OF THE Constitution 424 (1928). 
In the ratifying conventions, the states, jealous of their rights to representation and fearful of the power of the majority, approved the Convention's restrictions on the legislative power to judge qualifications. ${ }^{33}$ Although more concerned about conceding Congress the power to regulate elections than with the power to judge qualifications of members, ${ }^{34}$ most would have agreed with Wilson Cary Nicholas of Virginia that "It has ever been considered as great security to liberty, that very few should be excluded from the right of being chosen to the legislature." 35 As he pointed out in arguing for ratification, the Constitution amply provided for this by requiring no qualifications other than age, citizenship, and residence. ${ }^{36}$

\section{B. The Congressional Practice}

In the period before the Civil War, Congress strictly limited its use of the power to judge the qualifications of members. ${ }^{37}$ In 1799 the House refused to expel Matthew Lyon who had been convicted under the Sedition Act and was still imprisoned when Congress convened. ${ }^{38}$ Indeed, the Federalists made no attempt to exclude him from his seat although they clearly commanded sufficient votes to succeed in barring him from the House. ${ }^{39}$ Nine years later an attempt to disqualify a Maryland representative who had been accused of being a pensioner of a foreign government and not residing in his congressional district was rejected by the House. ${ }^{40}$ The majority concluded that every person was eligible to a seat in the House unless expressly

33 Cf. id. at 423.

$342 \mathrm{~J}$. Elutot, Debates in the Several State Conventions on the Adoption of the FeDERAL Constitution 22-36, 530 (2d ed. 1836); 3 id. at 60.

353 id. at 8.

$36 \mathrm{Id}$.

37 Congress did, however, exercise its power to expel members once they were seated. In July 1797, William Blount was expelled from the Senate for a "high misdemeanor, entirely inconsistent with his public trust and duty as a Senator." 7 ANNAIs of Cong. 44 (1797). Allegedly, Blount had negotiated with the Indians on behalf of the British Govermment. In 1808, an attempt was made to expel John Smith for his participation in the Burr conspiracy. 17 AnNals of Cong. 42 (1808). Although the vote of 19 to 10 fell short of the required two-thirds majority, Smith concluded discretion was the better part of valor and resigned his seat in the Senate. Id. at 324; 1 J. Story, Commentarjes on the Constitution of the UNITED States 608 (5th ed. 1891).

389 annals of Cong. 2973 (1799).

39 The vote in the House was 49 to 45 for expulsion, with members splitting along Adams-Jeffersonian lines. 9 AnNars of Cong. 2973 (1799).

4018 Annals of Conc. 1849 (1808) (exclusion of Philip B. Key). A year earlier the House refused by a vote of 89 to 18 to exclude William McCreery, a Maryland representative who allegedly had not resided in his district for a sufficient time. 17 ANNals of Cong. 1237 (1807). 
disqualified by the Constitution; ${ }^{41}$ the chairman of the elections committee believed that it would have been a violation of the natural rights of the people for Congress or the states to impose additional qualifications for office. ${ }^{42}$

Following the Civil War, congressional practice was greatly altered as the power to exclude a duly elected representative expanded considerably..$^{43}$ This change was produced by the North's bitter enmity toward those who failed to support the Union cause during the war, and was effected by the Radical Republican domination of Congress. It was a shift brought about by the naked urgency of power and was given little doctrinal support.

Immediately after the war, the House challenged seven representatives from Kentucky, ${ }^{44}$ excluding two for disloyalty. ${ }^{45}$ Similarly the Senate, by a vote of 27 to 20,46 excluded a member from Maryland who it concluded was unable to take an oath of loyalty because of his sympathy with the cause of the Confederacy. ${ }^{47}$ In both cases Congress relied not on the disqualification provisions of section 3 of the fourteenth amendment but on a newly acquired, expansive view of its power to judge the qualifications of prospective members.

Congress did not, however, limit its power of exclusion to those accused of sedition. ${ }^{48}$ At the turn of the century efforts were made to

11 See, e.g., 18 Annals of Cong. 1495 (1808) (statement of Mr. Gardenier of New York). 4217 AnNals of Cong. 874 (1807).

43 This change was perhaps best described by William Pitt Fessenden who, speaking on January 22, 1868, declared: "[T] he power which we have under the Constitution to judge the qualifications of members of the body is not a mere arbitrary power, to be exerted according to the will of the individuals who may vote upon the subject. It ought to be a power subject to certain rules and founded upon certain principles. So it was up to a very late period, until the rebellion. The rule simply was, if a man came here and presented proper credentials from his State, to allow him to take the ordinary oath, which we all took, to support the Constitution, and be admitted, and if there was any objection to him to try that question afterward." CoNG. Grobe, 40th Cong., 2d Sess. 685 (1868). It is, however, easy to exaggerate the force of this change in practice. In most of the exclusion cases the votes were very close, with many members hesitant about claiming this power for the legislature.

44 Cong. Grobe, 40th Cong., 1st Sess. $468-79$ (1867).

45 Cong. GloBe, 40th Cong., 2d Sess. 1200, 3375 (1868) (exclusion of John Young Brown). Id. at 3375 (exclusion of John D. Young).

46 Id. at 1271 .

47 For the debates in the case, see id. at 1144-56, 1165-77, 1205-10, 1232-43, 1260-71. In the third session of the 40th Congress, the House refused to seat John H. Cristy of Georgia because he had given aid to the Confederacy. Cong. Grobe, 40th Cong., 3d Sess. 374 (1869).

18 The congressional practice in exclusion cases where the member was accused of corruption has been far from uniform. While in 1870 the House refused to exclude John C. Connor, who had been accused of beating soldiers and bribing the court martial which was to try him, 1 HINDs 488 , in the same session it excluded B. F. Whittemore, who had been chosen at a special election held after his expulsion from the House for having 
purge Congress of the polygamous Mormons. ${ }^{48}$ The House, gathering support from the earlier disloyalty cases, ${ }^{50}$ denied Brigham $H$. Roberts his seat for allegedly violating the Edmunds Act prohibition against polygamy. ${ }^{51}$

The power of Congress to exclude a representative became even more firmly established in later cases dealing with socialists critical of the American military involvement in World War I. In 1920 Victor L. Berger, one of the most influential socialists in the United States, was denied a seat in the House by an almost unanimous vote. ${ }^{.2}$ Berger's criticism of American military policy in a series of pacifist tracts published in the Milwaukee Leader were found by the majority in Congress to have constituted an act of disloyalty for which he could be excluded..$^{53}$ Even after his re-election at a special election called to fill his vacant seat, Congress persisted in its refusal to admit Berger to membership. ${ }^{54}$

Although the House made several attempts to exclude members, ${ }^{, 5}$ it did not succeed in barring a member again until the successful challenge to Powell. Exclusion was invoked by the Senate, however, in two cases involving excessive campaign expenditures. ${ }^{58}$

sold appointments at the military academy. The resolution to exclude him, although failing to receive a two-thirds majority, passed by 130 to 76. Id. at 487 .

19 One writer has observed that the Mormons present a classic example of the exexcise of vigorous congressional authority against people adjudged "bad." Roche, Civil Liberty in the Age of Enterprise, 31 U. Cur. L. REv. 103, 132-34 (1963).

50 Attempts were also made to expel Mormon senators who had been seated. See the case of Senator Cannon, 1 Hinds 493. See also Comment, The Julian Bond Case, 52 VA. L. REv. 1309, 1320-21 (1966). In the case of Senator Smoot, however, the efforts to expeI failed for want of the requisite two-thirds majority. 1 Hinds 557.

51 See 33 Cong. REc. 1177-1217 (1900). The House voted to refuse him admission by a vote of 268 to 50 with 36 not voting and rejected a resolution that he be seated because he met the stated qualifications by a vote of 244 to 81 with 29 not voting. Id. at 1216-17.

62 See Z. Chafee, Free Spezch in the United States 247 (1948), for a brief biography of Berger. The vote was 311 to 1, with 119 not voting. 58 Cong. REc. 8261 (1919).

63 For the debate over exclusion which included Berger's speech in his defense, a fascinating document of American socialism, see 58 Conc. REc. 8219-61 (1919).

54 Berger was re-elected by a vote of 24,350 to 19,566 . The House, however, voted 330 to 6 to exclude him for the second time. 6 C. Cannon, Precedents of the House of RepRESENTATIVES 60-61 (1935).

55 In the 69th Congress, 1st Session (1925-1926), the House considered expelling John W. Langley of Kentucky, who had been convicted of conspiracy. Langley, however, resigned his seat and the House never voted on his exclusion. Id. at $\$ 238$. In 1933 the House voted 230 to 75 not to exclude Francis $H$. Shoemaker of Minnesota who had been convicted of sending defamatory material through the mail. 77 CoNG. REc. 73-74, 131-39 (1938).

68 Senators Frank L. Smith of Illinois and William S. Vare of Pennsylvania were excluded in 1927 for making excessive expenditures. The vote in the case of Smith was 61 to 23, and 58 to 22 in that of Vare. Senate Subcomm. ON Privileges and Elections, Senate Comm. on Rules and Administration, Senate Elfction, Expulsion and Gensure GASEs, S. DOC. No. 71, 87th Cong., 2d Sess. 119-23 (1962). 


\section{The State Practice}

Legislative exclusion in most states has conformed to the changing Congressional practice. Although some state constitutions explicitly limit the legislature to judging stated qualifications, most contain language identical to that of the United States Constitution. ${ }^{57}$ Following the example of Congress, most states initially excluded legislators only for a lack of stated qualifications. ${ }^{58}$ But by 1900 , they too had adopted a wider view of the power to judge qualifications. For example, in January, 1920, just before the second exclusion of Berger, the New York House of Representatives succeeded in excluding five socialists, including some who had been members of the legislature in the previous session, even though they met the stated qualifications of age and residence. ${ }^{59}$

\section{Judicial Review of Legislative Exclusion}

Although judicial restraint in reviewing cases of legislative exclusion was not clearly compelled by the Constitution, ${ }^{60}$ the Court had steadily narrowed its power of review before Bond $v$. Floyd. ${ }^{61}$ While in the

$57 \mathrm{It}$ is interesting to note that the language of the constitutional provision was taken from William Penn's charter to Pennsylvania of 1701. A provision similar to that adopted by the Convention was to be found in the constitutions of Delaware, Maryland, North Carolina, Pennsylvania and South Carolina. Warren observed: "There is, so far as appears, no instance in which a State Legislature, having such a provision in its Constitution, undertook to exclude any member for lack of qualifications other than those required by such Constitution." C. WARREN, The Making of the Constrtution 428 (1928). Indeed, the constitutions of Massachusetts and New Hampshire provided that the legislature was to judge the qualifications of their own members "as pointed out in the Constitution." Id. at 424.

58 Id. at 423.

59 See Z. Chafee, Free Speech IN the United States 269-82 (1948). This action was strongly protested by the New York bar led by Charles Evans Hughes. For the remonstrance signed by Hughes, Morgan J. O'Brien, Louis Marshall, Joseph M. Proskauer, and Ogden I. Mills, who headed a special committee of the New York bar to protest the exclusion of the socialists, see 5 N.Y. Legrs. Doc. No. 30, 143d Sess. (1921).

60 See notes 98-94 and accompanying text infra.

61 State courts followed a similarly restrictive practice often holding that the state constitution intended the legislature to have sole power to judge the qualifications of members. See, e.g., Young v. Boles, 92 Ark. 242, 122 S.W. 496 (1909); In re McGee, 36 Cal. 2d 592, 226 P.2d 1 (1951); Allen v. Lelande, I64 Cal. 56, 127 P. 643 (1912); French v. Senate, 146 Cal. 604, 80 P. 1031 (1905); English v. Bryant, 152 So. 2d 167 (Fla. 1963); Beatty v. Myrick, 218 Ga. 629, 129 S.E.2d 764 (1963); Rainey v. Taylor, 166 Ga. 476, 143 S.E. 383 (1928); Fowler v. Bostick, 99 Ga. App. 428, 108 S.E.2d 720 (1959); Reif v. Barrett, 355 Ill. 104, 188 N.E. 889 (1983); State ex rel. Acker v. Reeves, 229 Ind. 126, 95 N.E.2d 838 (1951); Lucas v. McAfee, 217 Ind. 534, 29 N.E.2d 403 (1940); Raney v. Stovall, 361 S.W.2d 518 (Ky. 1962); Greenwood v. Registrars of Voters, 282 Mass. 74, 184 N.E. 390 (1933); Dinan v. Swig, 223 Mass. 516, 112 N.E. 91 (1916); Hiss v. Bartlett, 69 Mass. (3 Gray) 468 (1855); Bowling v. Weakley, 181 Md. 496, 30 A.2d 791 (1943); Attorney Gen. v. Board of 
period following the Civil War the Court had examined whether state removal of an elected official constituted a denial of due process, ${ }^{62}$ by $1900^{63}$ it had adopted a much more restricted view. ${ }^{64}$ This contraction of judicial review became even more apparent in subsequent cases involving the right of federal ${ }^{65}$ and state legislators to be seated.68 Apparently fearful of encroaching on powers assumed by both federal and state legislatures, the judiciary generally refused to intervene on the grounds that legislative exclusion presented a nonjusticiable political question. ${ }^{67}$

Canvassers, 155 Mich. 44, 118 N.W. 584 (1908); State ex rel. Ford v. Cutts, 53 Mont. 300, 163 P. 470 (1917); Laxalt v. Cannon, 80 Nev. 588, 397 P.2d 466 (1964); Brown v. Lamprey, 106 N.H. 121, 206 A.2d 493 (1965); Monaghan v. School Dist. No. 1, 211 Ore. 360, 315 P.2d 797 (1957); Lessard v. Snell, 155 Ore. 293, 63 P.2d 893 (1987); Scott v. Thornton, 284 S.C. 19, 106 S.E.2d 446 (1959); Andersen v. Blackwell, 168 S.C. 137, 167 S.E. 30 (1932). But see People ex. rel. Hoyne v. McCormick, 261 IIl. 413, 103 N.E. 1053 (1913); Imbrie v. Marsh, 3 N.J. 578, 71 A.2d 352 (1950). For a discussion of the applicable Georgia provisions, see Comment, The Julian Bond Case, 52 VA. L. REv. 1309, 1319-24 (1966).

62 In both Kennard v. Louisiana, 92 U.S. 480 (1875), and Foster v. Kansas, 112 U.S. 201 (1884), the Supreme Court held that the removal of a state official violated no constitutional guarantee since the state procedure for removal had been followed. However, in Boyd v. Nebraska, 143 U.S. 135 (1891), the Court declared that the gubernatorial candidate who had received the majority of votes for office had been wrongfully excluded from office on the grounds that he was not a citizen of the United States.

63 The change was foreshadowed by Wilson v. North Carolina, 169 U.S. 586 (1898), in which the Court rejected as without substance the claim of the state railroad commissioner that his dismissal had denied him due process of law.

64 The change came with the case of Taylor \& Marshall v. Beckham, 178 U.S. 548 (1900), which grew out of the Kentucky General Assembly's decision that the candidates who had received a minority of the popular votes for governor and lieutenant governor were entitled to the officer rather than the candidates who had received a majority of the votes. Deciding that the right of an elected official to office did not come within the purview of the due process clause since an office was not property, and dismissing the contention that the action of the general assembly violated the guarantee of a republican form of government, the Court refused jurisdiction. Like the court of appeals, the Court concluded that the issue was a purely political question. This new attitude of judicial restraint seems to have been a by product of the Court's adoption of the doctrine of dual federalism in the economic sphere.

65 In Barry v. United States ex rel. Cunningham, 279 U.S. 597 (1929), the Court, in upholding the power of Congress to subpoena a witness, noted that the Senate had great discretion in refusing to seat a member. The case arose out of the exclusion of Senators Vare and Smith, who had been accused of making excessive campaign expenditures. The two opposing positions on the power of the Senate to exclude were ably argued by James M. Beck in his book, The Vanishing Rights of States (1926), and Price Wickersham in a Senate report supporting exclusion, S. Doc. No. 4, 70th Cong., 1st Sess. (1927). The refusal of the judiciary to intervene has been even more clearly pointed out in several lower court cases. See Johnson v. Stevenson, 170 F.2d 108 (5th Cir. 1948), cert. denied, 336 U.S. 904 (1949); Sevilla v. Elizalde, 72 App. D.C. 108, 112 F.2d 29 (1940).

68 See, e.g., Snowden v. Hughes, 321 U.S. 1 (1944).

or Interestingly, the political question doctrine was not applied as a principle of substantive law in either Taylor or the later election cases; rather it was used to restrict the application of other principles of substantive law governing the controversies and make their application much less stringent. 
The Court's use of the political question doctrine to avoid judicial review of the removal or exclusion of elected officials paralleled its use of the doctrine in cases of legislative apportionment; ${ }^{68}$ thus, it is not surprising that the downfall of the political question doctrine in the state exclusion cases followed soon after its collapse in the apportionment cases. ${ }^{69}$ Although the Court made a cautious exception to the political question doctrine in Gomillion v. Lightfoot ${ }^{70}$ when it found Tuskegee's efforts to exclude Negroes by altering its city limits a violation of the fifteenth amendment, ${ }^{71}$ it was in Baker v. Carr ${ }^{72}$ that the Court opened the way for judicial review of state legislative exclusion. ${ }^{73}$ Noting that the nonjusticiability of a political question resulted primarily from the separation of powers in the United States Constitution, ${ }^{74} \mathrm{Mr}$. Justice Brennan concluded in his opinion for the Court: "[I]t is the relationship between the judiciary and the coordi-

68 See Colegrove v. Green, 328 U.S. 549 (1946) (opinion of Frankfurter, J.). For an analysis of the "contribution" of Colegrove, see Friedelbaum, Baker v. Carr: The New Doctrine of Judicial Intervention and Its Implications for American Federalism, $29 \mathrm{U}$. CHI. L. REv. 673, 678 (1962).

69 See, e.g., Reynolds v. Sims, 377 U.S. 533 (1964); Wesberry v. Sanders, 376 U.S. 1 (1964); Baker v. Carr, 369 U.S. 186 (1962).

70364 U.S. 339 (1960).

71 Although the right of a city to determine its boundaries had previously been regarded as beyond judicial review, the Court in Gomillion refused to acquiesce in its use to violate the requirements of the fifteenth amendment. For an entertaining discussion of the case, see Lucas, Dragon in the Thicket: A Perusal of Gomillion v. Lightfoot, 1961 SUP. CT. REv. 194.

72369 U.S. 186 (1962).

73 Id. For a complete discussion of the case, see Neal, Baker v. Carr: Politics in Search of Law, 1962 SuP. Cr. REv. 252. Rejecting the broad formulation which Mr. Justice Frankfurter had given the political question doctrine in Colegrove, Mr. Justice Brennan noted: "The courts cannot reject as 'no law suit' a bona fide controversy as to whether some action denominated 'political' exceeds constitutional authority. The cases we have reviewed show the necessity for discriminating inquiry into the precise facts and posture of the particular case, and the impossibility of resolution by any semantic cataloguing." 369 U.S. at 217. See also Emerson, Malapportionment and Judicial Power, 72 YALE L.J. 64, 79 (1962).

74 For a criticism of Mr. Justice Brennan's analysis of the political question doctrine, see Scharpf, Judicial Review and the Political Question: A Functional Analysis, 75 YALE L.J. 517, 598 (1966). This position was more thoroughly developed by Professor Weston in 1925. Weston attempted to demonstrate that in every instance: "[T] judicial and political questions . . . is the line drawn by the constitutional delegation, and none other." Weston, Political Questions, 38 HArv. L. REv. 296, 391 (1925). Professor Finkelstein in a reply to Weston argued: "[I]t is not only true . . that the doctrine of the separation of powers has proven quite useless as a principle, or even as a guide for the decision of cases; but, more important for present purposes, it is quite plain that no matter what merits the doctrine may contain, it has little relevance to the determi. nation of what are, and what are not, questions suitable for judicial review." Finkelstein, Further Notes on Judicial Self-Limitation, 39 HARv. L. REv. 221, 223 (1926). Scharpf has provided an even more persuasive refutation of the Weston-Brennan position. Scharpf, supra at 540-48. 
nate branches of the Federal Government, and not the federal judiciary's relationship to the States, which gives rise to the 'political question." "75

The decision of the Court in Bond v. Floyd, adopting Mr. Justice Brennan's interpretation, eliminated the political question limitation in cases of state legislative exclusion. Ignoring the earlier precedents in which the political question doctrine had been used to avoid judicial review of the right of a state official to office, ${ }^{78}$ the Court rejected the state's argument that the judiciary had no power to review the legislature's power to judge whether a prospective member could conscientiously take the required oath of office ${ }^{77}$ and concluded that the Georgia House of Representatives had acted unconstitutionally in excluding Bond. ${ }^{88}$

Yet even after Bond established that the political question doctrine poses no barrier to judicial review of state action, the doctrine could remain a bar to review of congressional exclusion, as the district court's decision in the Powell case points out. ${ }^{79}$

Baker v. Carr, ${ }^{80}$ the Court's most exhaustive analysis of the political question doctrine, indicated that the doctrine might prevent judicial review of the actions of another branch of the federal government. In Baker, Mr. Justice Brennan, writing for the Court, rejected earlier attempts to establish categories of " 'political question' cases"81 and argued that determining whether a case presented a nonjusticiable political question was a matter of constitutional interpretation demanding a discriminating inquiry into the precise facts and posture of each case. ${ }^{82}$ In his attempt to isolate the analytical threads of the political question doctrine, he advanced six factors which may indicate the presence of a nonjusticiable political question. ${ }^{83}$ His first

75369 U.S. at 210. For a discussion of the impact of this statement, see Emerson, Malapportionment and Judicial Power, 72 YALE L.J. 64, 66 (1962).

78 E.g., Taylor \& Marshall v. Beckham, 178 U.S. 548 (1900).

77385 U.S. at 131.

78385 U.S. at 137.

79 Powell v. McCormack, 266 F. Supp. 354, 359-60 (D.D.C. 1967).

80369 U.S. 186 (1962).

81 Id. at 210.

82 Id. at 211.

83 Id. at 217. He declared: "Prominent on the surface of any case held to involve a political question is found a textually demonstrable constitutional commitment of the issue to a coordinate political department; or a lack of judicially discoverable and manageable standards for resolving it; or the impossibility of deciding without an initial policy determination of a kind clearly for nonjudicial discretion; or the impossibility of a court's undertaking independent resolution without expressing lack of the respect due coordinate branches of government; or an unusual need for unquestioning adherence to 
formulation bears special relevance to the present discussion.84 Adopting the classic view that the political question doctrine was a product of the separation of powers," he concluded: "Prominent on the surface of any case held to involve a political question is found a textually demonstrable constitutional commitment of the issue to a coordinate political department." 86 Consequently, any inquiry into the power of the judiciary to review the exclusion of a member of Congress must begin with an analysis of the Constitution itself.

Although the Constitution declares only that "Each House shall be the Judge of the Elections, Returns and Qualifications of its own Members ... , "87 several commenators have argued, that the text of the Constitution puts review of the exercise of this authority by Congress beyond the power of the judiciary. ${ }^{88}$ Professor Wechsler has

a political decision already made; or the potentiality of embarrassment from multifarious pronouncements by various departments on one question."

The second factor advanced by Mr. Justice Brennan-the need for a judicially manageable standard-would seem to pose no problem for judicial review of legislative exclusion since there are a number of judicially manageable standards which the Court could adopt. See section IV infra. His third criterion-the impossibility of deciding without an initial policy determination of a kind clearly for nonjudicial discretion-would prevent the Court from merely substituting its judgment of the wisdom of the legislature's action, but should not restrict the Court's ability to make a principled adjudication based on its interpretation of the Constitution. In any event it would seem to pose more of a barrier to review of legislative apportionment than it does to legislative exclusion.

The last two criteria-the unusual need for unquestioning adherence to a political decision already made and the potentiality of embarrassment from multifarious pronouncements by various departments on one question-would seem to have exclusive reference to review of the foreign policy activities of the Executive. Both would prevent the Court from reviewing the President's exercise of the power of recognition. It would also prevent review of the executive power questioned in Luther v. Borden, 48 U.S. (7 How.) 1 (1849).

The fourth could, however, pose a barrier to judicial review. Although it is not altogether clear what Mr. Justice Brennan intended when he stated that a case presented a nonjusticiable political question when there was "the impossibility of a court's undertaking independent resolution without expressing lack of the respect due coordinate branches of government," if this referred to the problem of an effective remedy, the problem is easily solved in the legislative exclusion cases. See note 107 and accompanying text infra. If it were intended to refer to the method by which the court disposes of a case it would seem to be only slightly different from his requirement preventing the judiciary from deciding a dispute when it would involve an initial policy determination of the kind clearly for nonjudicial discretion. In any event, this criterion need not bar relief if the Court rests its decision on a provision of the Constitution such as the frrst amendment. See discussion in section IV infra.

84369 U.S. at 217.

85 See note 74 supra.

86369 U.S. at 217.

87 U.S. CoNST. art. I, \& 5.

88 E.g., Frank, Political Questions, in Supreme Court and Supreme LAw 36 (E. Cahn ed. 1954). Cf. Gooch, Book Review, 13 VA. L. REv. 670, 671 (1927). But see Book Review, 2 NOTRE DAME LAW. 175, 176 (1927). 
concluded that the power of Congress to judge the qualifications of a member, like the Senate's power to try an impeachment, is beyond judicial review. ${ }^{89}$ Rejecting this interpretation, Professor Scharpf has advocated a more elaborate and convincing interpretation of these two constitutional provisions. ${ }^{00}$ He reasoned that because both powers are adjudicative rather than legislative or executive, "It may therefore be reasonable to construe the express constitutional authorization of Congress to decide these disputes as an equally explicit exception to the general grant of judicial power to the courts in Article III."91 Yet even if Professor Scharpf's interpretation were accepted, some judicial review would be permitted. It would still fall to the Court, as the final arbiter of the constitutional allocation of power among the branches, to determine if the Constitution granted Congress the power to judge qualifications not stated in the Constitution..$^{92}$

The language of the Constitution would seem, in any case, to be a poor indicator of the presence of a nonjusticiable political question. In granting the houses of Congress the power to judge the qualifications of their members, the Constitution does not declare that each is the sole judge of the qualifications of its members as it does when it grants the Senate the sole power to try impeachments. ${ }^{93}$ Because the Constitution merely confers upon Congress the power to judge qualifications, Professor Bickel has argued: "[T] here is no textual reason why these duties and functions of Congress should be deemed proof against judicial intervention, any more than the language of the commerce clause, which provides that 'Congress shall have Power ... To regulate Commerce with foreign nations' is read to foreclose judicial review."94

Because of the ambiguity in the language of the Constitution, a determination of whether exclusion presents a political question should rest not on these "textual interpretations,"95 but upon an evaluation of the legitimacy of judicial review of this legislative power and a consideration of any functional difficulties which might preclude

80 Wechsler, Toward Neutral Principles of Constitutional Law, 73 HARv. L. Rev. 1, 8 (1959).

90 Scharpf, supra note 74 , at 540 .

91 Id.

82 As Professor Scharpf has noted, the political question doctrine has not been permitted to gain a permanent foothold at the core of the Court's constitutional responsibility for the determination of conflicts of competence among the branches of government. Id. at 596.

93. Compare U.S. Consr. art. I, \$ 5, with id. \$ 3.

84 Bickel, The Durability of Colegrove v. Green, 72 Yale L.J. 39, 40 (1962).

85 For a criticism of this approach to the political question doctrine, see Scharpf, supra note 74 , at $538-48$. 
effective review. ${ }^{96}$ In a democratic society the use of judicial review to challenge the judgment of the legislature should be extraordinary and must be justified by competing demands of democratic theory. ${ }^{97}$ Moreover, it must be demonstrated that the Court can obtain and evaluate the information necessary for an effective decision and tailor an adequate remedy. If these considerations are met, the Court should not be barred from review by the political question doctrine.

The institutional capacity of the Court to define and protect the fundamental values of a democratic society-such as the right of the electorate to choose its elected representatives-makes review of the legislature's use of the power to judge the qualifications of members a legitimate exercise of judicial power. Because the legislature is by its very nature dominated by majority pressures and subject to the demands of expediency, ${ }^{98}$ it is unable to decide specific disputes over the qualifications of members in terms of seemingly abstract democratic principles. Unlike the legislature, the Court, standing above faction, can pronounce and define principle ${ }^{99}$ and provide the "sober second thought" of the political community.

The legitimacy of judicial review when fundamental individual rights ${ }^{101}$ are threatened has severely restricted the Court's application of the political question doctrine. ${ }^{102}$ Even in foreign affairs, where

96 The importance of these functional considerations for judicial review has been thoroughly developed by Scharpf. See id. at 566-97.

97 Professor Bickel has made this point eloquently. A. Bicker, The LEAST Dangerous Branch 6 (1962).

98 Professor Emerson has observed in another context: "[D]f we compare the legislative and executive branches of government with the judicial, it is apparent that the judiciary is the chief institution of the state capable of affording the necessary degree of legal support for a system of free expression. The legislature is subject to the most direct, immediate and constant pressure from the majority or powerful minorities." Emerson, Toward a General Theory of the First Amendment, 72 YALE L.J. 877, 897 (1963).

99 Perhaps the best definition of a decision based upon neutral principle is that of Professor Wechsler: "A principled decision, in the sense $I$ have in mind, is one that rests on reasons with respect to all issues in the case, reasons that in their generality and their neutrality transcend any immediate result that is involved." Wechsler, supra note 89 , at 19.

100 See A. Bicker, supra note 97, at 23-28. But cf. Gunther, The Subtle Vices of the "Passive Virtues," 64 Colum. L. REv. 1 (1964).

101 That the right to vote is a fundamental right has been clearly recognized by the Court in the apportionment cases. Mr. Justice Black, in holding Georgia's congressional districting system unconstitutional, declared: "No right is more precious in a free country than that of having a voice in the election of those who make the laws under which, as good citizens, we must live. Other rights, even the most basic, are illusory if the right to vote is undermined." Wesberry v. Sanders, 376 U.S. 1, 17 (1964) (dicta). See also Reynolds v. Sims, 377 U.S. 533 (1964).

102 Indeed, Professor Scharpf has concluded: "[W] here important individual rights are at stake, the doctrine will not be applied." Scharpf, supra note 74 , at 584 . 
the argument for abstention is most compelling because of the judiciary's inability to obtain information and the need for unity, the Court has not hesitated to enforce the standards of the Bill of Rights in at least one series of cases. ${ }^{108}$

Review of legislative exclusion presents few functional difficultiesfar fewer indeed than presented by the reapportionment cases. Because a decision would depend upon adjudicative facts and not legislative facts, ${ }^{104}$ which are by definition difficult for the judiciary to obtain and use, judicial review would seem particularly appropriate. ${ }^{105}$ In fact, both West Germany and Great Britain have made the judiciary responsible for determining the qualifications of members of the legislature. ${ }^{108}$

Shaping an effective remedy that would not unduly antagonize the legislature would also seem to present little difficulty. ${ }^{107}$ While, of course, some possibility of conflict between the judiciary and the legislature remains, ${ }^{108}$ it would seem less than in the reapportionment

108 McElroy v. United States ex rel. Guagliardo, 361 U.S. 281 (1960); Kinsella v. United States ex rel. Singleton, 361 U.S. 234 (1960); Reid v. Covert, 354 U.S. 1 (1957). For an argument which would rest a decision on the first admendment, see Part IV infra.

104 The distinction between adjudicative and legislative facts has been developed and exhaustively elaborated by Professor Dapis. See, e.g., 2 K. Davis, Administrative LAw TREATISE 15.08 (1958); Davis, Judicial Notice, 55 ColUM. L. REV. 945, 952-59 (1955); Davis, An Approach to Problems of Evidence in the Administrative Process, 55 HARv. 1. REv. 364, $402-10$ (1942).

105 For a discussion of the use of legislative facts in constitutional litigation, see Baade, Social Science Evidence and the Federal Constitutional Court of West Germany, $23 \mathrm{~J}$. Porrrics 421 (1961); Karst, Legislative Facts in Constitutional Litigation, 1960 Sup. Cr. REv. 75.

106 The West German Grundgesetz provides that the Bundestag retains primary jurisdiction over election cases but allows an appeal to the Federal Constitutional Court by a member who has been denied his seat. GrundGesErz, art. 41(1), (2). In Britain the role is reversed, with the judiciary making the initial determination of eligibility. Parliamentary Elections Act of 1868, 31 \& 32 Vict., c. 125. See generally E. MAY, Pardinumentary Practice 192-201 (17th ed. 1964).

107 The Court could dispose of any dispute by simply holding the refusal of Congress to seat a member unconstitutional as it did in Bond. 385 U.S. at 137. If this declaratory form of relief failed, it could issue a mandatory injunction compelling the sergeant-atarms to seat the excluded member. Both of these remedies would avoid the antagonism that would almost certainly be engendered by a decision which depended upon enjoining each member of the legislature for its enforcement. Indeed, the availability of these remedies which avoid any direct confrontation with the legislature make conflict in the case of legislative exclusion far less likely than the more extreme relief that could be required in the reapportionment cases.

108 Although some commentators have attempted to explain the political question doctrine solely in terms of the Court's avoidance of potential conflict, e.g., Finkelstein, Judicial Self-Limitation, 87 HARv. L. Rev. 338 (1924); Finkelstein, Further Notes on Judicial Self-Limitation, 39 HARv. L. Rev. 221 (1925), such an analysis cannot withstand a close examination of the prior decisions of the Court. See, e.g., Worcester v. Georgia, 31 U.S. (6 Pet.) 515 (1832); Ex parte Merryman, 17 Fed. Cas. 144 (No. 9487) (Cir. Ct. Md. 
cases. ${ }^{109}$ In any event, if a case involves questions of great importance to the democratic process, as the Powell case does, the Court should not refuse to intervene because there is a measure of congressional hostility to judicial review of legislative actions.

\section{A Standard for Decision}

Assuming that review of legislative exclusion is not barred by the political question doctrine, it remains for the Court to formulate a standard by which the constitutionality of the legislature's exercise of its power to judge qualifications may be measured. Two approaches appear open to the Court. It could establish a standard based upon the language and history of the constitutional provision granting Congress the power to judge qualifications, or it could derive a standard from limitations contained in other portions of the Constitution such as the first amendment.

\section{A. Article I, Section 5-The Judicial Understanding}

The most direct approach would be for the Court to hold that both the langauge of the Constitution and the intention of the framers confined the congressional power to judge qualifications to an examination of the age, citizenship, and residency of its members. The difference in language between the constitutional grant of the power to expel or punish a member and its grant of power to judge qualifications seems to support this result. ${ }^{110}$ While the power to punish or expel is not limited by the language of the Constitution, ${ }^{111}$ the power to judge qualifications is restricted by the enumeration of qualifications elsewhere in Article I. ${ }^{112}$ Moreover, such a difference is supported by the intention of the framers ${ }^{113}$ and the practice of Congress in the period before the Givil War. ${ }^{114}$

1861) (Taney, Circuit Justice). But cf. Colegrove v. Green, 328 U.S. 549 (1946); Georgia v. Stanton, 73 U.S. (6 Wall.) 50 (1867); Mississippi v. Johnson, 71 U.S. (4 Wall.) 475 (1866). Professor Scharpf has done an excellent job of restricting these "prudential" theories to their proper limits. Scharpf, supra note 74, at 548-55.

109 This would seem particularly true if the Court were to rest its decision on the provisions of the first amendment. See note 116 and accompanying text infra.

110 U.S. CoNST. art. I, \& 5.

111 Some have argued, however, that this power is limited to acts of the legislator during the session of Congress. This would seem to be an unnecessarily narrow reading of the constitutional provision and, indeed, has served merely as a justification for a wider power of exclusion in most cases. One could also argue that the rationale of the Bond case prevents Congress from expelling a member to silence his unpopular statements.

112 U.S. CONST. art. I, $\$ 2,3$.

113 See notes $19-36$ and accompanying text supra.

114 See notes $37-42$ and accompanying text supra. 
Such a standard would prevent Congress from imposing additional qualifications and consequently would make the exclusion of Adam Clayton Powell by the House unconstitutional. It would deny Congress the power to exclude by a mere majority vote a legislator whose views it found obnoxious while preserving the congressional power to expel by a two-thirds vote.

\section{B. The First Amendment}

The Court could also rest its decision upon a standard derived from limitations contained in provisions of the Constitution other than article $I$, section 5 . While several portions of the Constitution might prove applicable, ${ }^{115}$ a standard is most clearly revealed in both the policy and recent judicial interpretation of the first amendment. As the Court pointed out in Bond, legislative refusal to seat a duly elected representative who met the formal qualifications for office might violate the first amendment. Moreover, a decision based on the first amendment would probably restrict the impact of the political question doctrine and reduce the possibility of conflict with the legislative branch. ${ }^{116}$

1. The Representative-The Right to Speak. That the first amendment prohibits the legislature from excluding a member for statements which he has made on political issues was demonstrated in Bond. In holding the actions of the Georgia House in twice excluding Bond unconstitutional, the Court, ignoring tests previously used in similar public employee ${ }^{117}$ and draft resistance cases, ${ }^{118}$ adopted the

115 For example, Powell, like Bond, has argued that the legislature's action was in the nature of a prohibited bill of attainder because it constituted a legislative judging and punishment. Brief for Appellant at 52.54, Powell v. McCormack, - F.2d - (D.C. Cir. 1967). This argument would seem to be unduly broad, however, and if taken seriously could deny all legislative power to judge qualifications or punish members for disorderly conduct. Powell has also argued that his exclusion was a denial of due process and a violation of the 13th, 14th, and 15th amendments. Id. at 54-59. Both of these arguments are peculiar to the Powell case and consequently cannot provide a standard for judging the legislature's power to exclude.

116 Framing the decision in terms of the first amendment would seem to eliminate much of the potential conflict presented if the Court were merely to substitute its interpretation of article 1 , section 5 , for that of the legislature. A decision based on the first amendment would seem to be supported by a "neutral" standard of constitutional law and, consequently, would be more readily accepted by the Iegislature. Moreover, such a decision would make it clear that the Court intervened to protect an important individual right and would be supported by earlier decisions Iestricting the doctrine of political questions. See note 103 supra and accompanying text.

117 Before its recent decision in Keyishian . Board of Regents, 385 U.S. 589 (1967), holding a loyalty oath required of New York teachers to be unconstitutional, the Court had used the balancing test to determine whether a regulation infringed a public employee's first amendment rights. See, e.g., Konigsberg v. State Bar, 366 U.S. 36 (1961); In re 
approach to the first amendment formulated in New York Times $v$. Sullivan:118 "The central commitment of the First Amendment . . is that 'debate on public issues should be uninhibited, robust and wideopen." "120 The Court rejected the argument that federalism and the concept of separation of powers required a less stringent application of the first amendment, ${ }^{121}$ and, applying the Times principle, concluded that the speech of a legislator on political issues could not be suppressed by the legislature's use of its power to judge the qualifications of members. ${ }^{122}$ The Court declared: "The manifest function of the First Amendment in a representative government requires that legislators be given the widest latitude to express their views on issues of policy."123

If judicial intervention were not precluded by the political question doctrine, the Court's decision in Bond would appear to prohibit Congress from imposing qualifications in addition to age, residence, or citizenship in order to exclude a representative whose statements it found obnoxious. Indeed, the rationale of Bond might even restrict congressional power to judge the stated qualifications if that power

Anastaplo, 336 U.S. 82 (1961); Nelson v. County of Los Angeles, 362 U.S. I (1960). The unstated premise behind these cases was that public officials could always exercise their first amendment rights by resigning. See Adler v. Board of Education, 342 U.S. 485 (1952); Garner v. Board of Public Works, 341 U.S. 716 (1951); American Communications Ass'n v. Douds, 399 U.S. 382 (1950). But cf. Keyishian v. Board of Regents, 385 U.S. 589 (1967); Baggett v. Bullitt, 377 U.S. 360 (1964); Torcaso v. Watkins, 367 U.S. 488 (1961).

118 In this area the Court has consistently used the "clear and present danger" test to appraise the illegality of the advocacy. See Schenck v. United States, 249 U.S. 47 (1919); Gara v. United States, 178 F.2d 38 (6th Cir. 1949) (relied on by the lower court in Bond but not discussed by the Supreme Court). Yet, in view of the recent decline of the test as a cannon of constitutional interpretation, the Court's failure to invoke it in Bond was hardly surprising.

119376 U.S. 254 (1964).

120385 U.S. at 136. The Court went on to declare: "We think the rationale of the New York Times case disposes of the claim that Bond's statements fell outside the range of constitutional protection." Id.

121 Such an argument has frequently been made but has received little support from the Court. See, e.g., Bond v. Floyd, 251 F. Supp. 333, 340 (N.D. Ga. 1966); Beauharnais v. Illinois, 343 U.S. 250, 287 (1952) (dissent of Jackson, J.); Roth v. United States, 354 U.S. 476, 496 (1957) (separate opinion of Harlan, J.). For a theoretical argument supporting the use of federalism in the free speech context, see Anastaplo, Notes on the First Amendment (unpublished Ph.D. thesis, University of Chicago 1964). But see Bond v. Floyd, 251 F. Supp. 333, 345 (N.D. Ga. 1966) (dissent Tuttle, C.J.); Emerson, Toward a General Theory of the First Amendment, 72 YALE L.J. 877, 906 (1963). For a discussion of the impact of the Court's earlier rejections of this argument in Times and a general development of the significance of the Times decision, see Kalven, The New York Times Case: $A$ Note on "The Central Meaning of the First Amendment," 1964 Sur. Cr. REv. $191,218$.

122385 U.S. at 137.

$123 I d$. at 136. 
were used as a device to deny the representative his right to freedom of speech. Thus, it seems clear that the House of Representatives could not have excluded Powell on the basis of his statements endorsing the black power movement.

While the Bond decision disposed of most cases of legislative exclusion, it provides little guidance for review of those cases in which the duly elected and apparently qualified legislator is excluded for a reason other than his political statements. Such is the problem presented by the Powell case. ${ }^{124}$ Unlike Bond, Powell would not seem to have been denied his seat because he made unpopular statements; rather the challenge emanated from charges of corruption and Powell's failure to satisfy the New York libel judgment against him. ${ }^{126}$ Such activities are not speech protected by the first amendment. Powell, therefore, has no grounds for contending that his exclusion was a device to deny him his freedom of speech.

2. The Electorate-The Right To Choose a Representative. Although the Court in Bond did not directly consider any question other than the right of the representative to speak, the rationale of Bond and the interpretation of the first amendment adopted in the New York Times case might provide a standard for decision in a case like Powell. At its broadest, the New York Times principle seems to pro. hibit governmental action which suppresses political speech unless the restriction were consented to by the electorate and embodied in the Constitution. ${ }^{128}$ It would seem to protect not only the right of the representative to speak on political issues but also the right of the electorate to vote-its principal form of political speech. Moreover, as in the construction of other first amendment rights there should be a strong presumption against any limitation on the right to vote. Thus, only those qualifications clearly expressed in the Constitution could restrict the electorate's right to select its representative. While the electorate has waived its complete freedom to vote as it chooses by consenting to the constitutional qualifications of age, residence, and

124 See generally 113 CoNG. REc. H4-16 (daily ed. Jan. 10, 1967), H1918-57 (daily ed. March 1, 1967).

126 See id. at F1818 (daily ed. March 1, 1967).

126 While the Court's decision was obviously confined to the narrow libel context, the principle of the Times case was a clear recognition that the first amendment protected political speech. See 376 U.S. at 275. As Mr. Justice Brennan observed of the decision: "[T] and concluded that meaning was revealed in Madison's statement 'that the censorial power is in the people over the Government and not in the Government over the people." Brennan, The Supreme Court and the Meiklejohn Interpretation of the First Amendment, 79 HARv. L. REv. 1, 15-16 (1965). See also Kalven, supra note 121, at 208-09. 
citizenship, ${ }^{127}$ the first amendment would deny the legislature the power to abridge the electorate's freedom to choose its representative by imposing qualifications not contained explicitly in the Constitution. Consequently, the action of the House in excluding Powell, who met the constitutional requirements of age, residence, and citizenship would be unconstitutional.

While the first amendment would thus prohibit the legislature from going beyond the enumerated qualifications for membership, it would not deny Congress all power to punish members for blameworthy conduct. The electorate's right to be represented by the person of its choice has been restricted by the constitutional provision granting Congress the power to punish members for disorderly conduct or to expel them by a two-thirds vote. ${ }^{128}$ Thus, the House could have punished Powell for his misuse of public funds just as the Senate censured Senator Dodd for his improper financial activities. Indeed, the House could have expelled Powell by a two-thirds vote once he had been seated. Instead, it chose to frame its action in terms of exclusion requiring only a simple majority vote and to incur the risk that its action might be held unconstitutional by the courts. ${ }^{129}$

While extending the first amendment to protect the right to vote as well as the right to speak admittedly depends on an extremely broad reading of the New York Times case, it finds some indirect support from the Court's opinion in Bond. In Bond the Court seemed to indicate that a restriction not contained in the Constitution and not consented to by the electorate might constitute a violation of the first amendment. ${ }^{130}$ In supporting his decision in Bond, Mr. Chief Justice Warren declared: "Legislators have an obligation to take positions on controversial political questions so that their constituents can be fully informed by them, and be better able to assess their qualifications for office: also so they may be represented in governmental debates by the person they have elected to represent them."131 This statement by the Chief Justice was a paraphrase of Madison's argument in his report on the Virginia Resolutions in which he contended that the Constitution prohibited the legislature from suppressing the representatives' right to speak and the electorate's right to select its representatives. ${ }^{132}$

127 For this type of argument, see 9 Annars of CoNG. 2964 (1799).

128 U.S. CoNsT. art. I, \& 5.

129 See, e.g., H.R. ReP. No. 27, 90th Cong., 1st Sess. 30 (1967).

130 See 385 U.S. at 136. It is interesting to note that the Court apparently believed that the framers intended the legislature to judge only those qualifications enumerated in the Constitution. Id. at 135-36, n.13.

131 Id. at 196-97 (emphasis added).

1324 J. Elliot, Debates in the Several State Conventions on the adoption of the 
The Court, like Madison, apparently recognized the importance of the power of the electorate to choose representatives as well as the right of representatives to speak on political issues.

The strongest support for this interpretation of the first amendment is to be found in the writings of Madison. Following the Convention, Madison, writing on the Sedition Act, argued that the right of electing members of the government constituted the essence of a free and responsible government. ${ }^{133}$ In his view, any limitation upon the power of the people to select their representatives not contained in the Constitution was inconsistent with the meaning of self government. ${ }^{134}$

Elaborating upon this view, Professor Alexander Meiklejohn has argued convincingly that the first amendment protects not only the right of the people to criticize their representatives but also their right to select and censor them through the power to vote. ${ }^{135}$ For him, it was the power to govern that the first amendment intended to protect against abridgment. ${ }^{136}$ Yet, Meiklejohn recognized that this right was subject to the regulations and limitations contained in the Constitution.

\section{Conclusion}

Judicial review of the exclusion of a representative to the United States Congress is both constitutionally possible and philosophically legitimate. The erosion of the political question doctrine at the hands of a Court which has adopted a philosophy of judicial activism in protecting individual rights has eliminated the principal barrier to judicial review of legislative exclusion. Moreover, both the historical understanding of article $I$, section 5 , and the interpretation of the first amendment apparently adopted by the Court in Bond provide a judicially manageable standard by which the Court could determine the constitutionality of a legislature's exercise of the power to exclude.

FEDERAI Constitution 575 (2d ed. 1836). Both the remarkable similarity to Madison's statement and the Court's frequent reliance on his writings elsewhere in the opinion would seem to compel the conclusion that it had paraphrased Madison.

133 Madison, Report on the Virginia Resalutions (1800), reprinted id.

134 Madison's interpretation of the first amendment was adopted by the Court in the Times case. See Brennan, supra note 126 , at 15 .

135 Meiklejohn, The First Amendment Is an Absolute, 1961 Sup. Cr. REv. 245. Meiklejohn declared: "The revolutionary intent of the First Amendment is, then, to deny to all subordinate agencies authority to abridge the freedom of the electoral power of the people." Id. at 254.

$136 I d$. at 256. For a somewhat similar but more detailed interpretation of the first amendment, see Emerson, Toward a General Theory of the First Amendment, 72 YaLE L.J. 877 (1963), and Emerson, Freedom of Association and Freedom of Expression, 74 YALE L.J. 1 (1964). 